\title{
BRAIN DRAIN - BRAIN GAIN: SLOVAK STUDENTS AT CZECH UNIVERSITIES
}

Jakub Fischer ${ }^{1}$, Hana Lipovská ${ }^{\bowtie}$

${ }^{1}$ Department of Economic Statistics, Faculty of Informatics and Statistics, University of Economics, Prague, Czech Republic, fischerj@vse.cz ${ }^{2 \bowtie}$ Department of Economic, Faculty of Economics and Administration, Masaryk University, Lipová 41a, Brno, 602 00, Czech Republic, +420723741383, lipovska.hana@seznam.cz

\author{
Highlights \\ - The emigration to the Czech Republic for education is serious problem for Slovakia \\ - The Slovak brain drain is a Czech brain gain, because Slovak students at Czech HEIs are recruited from Slovak elite \\ - $\quad$ Only $6 \%$ of the Slovak doctoral students think about returning back to the Slovak Republic
}

Article type

Full research paper

Article history

Received: September 16, 2015

Received in revised form: October 19, 2015

Accepted: October 19, 2015

Available on-line: November 24, 2015 students at Czech HEIs enjoy certain social benefits, slightly more often they have higher monthly income compared to Czech students, and they work slightly less often during their studies. Finally, according to our findings, Slovak doctoral students are often reluctant to return back to the Slovak Republic or to stay in the Czech Republic.

\section{Keywords}

Brain gain, DOKTORANDI 2014, Eurostudent V, human capital, mobility, Slovak students

Lipovská H., Fischer J. (2015) "Brain Drain - Brain Gain: Slovka Students at Czech Universities", Journal in Efficiency and Responsibility in Education and Science, Vol. 8, No. 3, pp. 54-59, online ISSN 1803-1617, printed ISSN 2336-2375, doi: 10.7160/ eriesj.2015.080301.

\section{Introduction}

The most important of the any nation's assets is its human capital. However, human capital is such a complex combination of the human skills and abilities, that it is nearly impossible to measure it with the necessary accuracy. The most common proxy variable for the human capital level is, therefore, the highest education level of the individual (Mazouch, Fischer, 2011). This indicator is due to the unavailability of proper statistical data, further narrowed down to merely formal education. Formal education is supplied primarily by governments in current welfare states, which is connected to the funding from the public budget. Public funding of formal education is in many cases relatively expansive. The budget of the Ministry of Education, Youth and Sports of the Czech Republic accounts for $10 \%$ of the total state budget in 2015 (MF CR 2015). Most Western countries are therefore concerned with brain drain - the international transfer of human capital from developing to the developed countries (Rapoport 2002).

In the Central Europe region, brain drain is a serious problem, especially for the Slovak Republic. According to the Organisation for Economic Co-operation and Development (OECD), about $15 \%$ of Slovak students studied abroad in 2012 (OECD, 2014). The findings of the same report suggest that it is the third highest rate among OECD countries - after Luxembourg (where there is just one university so most of the students leave to Germany, France and Belgium) and Iceland (Icelandic students tend to study in Scandinavian countries and the United Kingdom).
Most of the Slovak students studying abroad settled in the Czech Republic (69\%, OECD 2014). This (ever growing) share is the logical result of the overall close relationships between the two bordering nations, which used to form a common federation. The similarity of languages, closeness of cultures and enduring family ties facilitate such an emigration for education (as called by Bahna, 2015). It has been made even easier thanks to the contract between the Ministry of Education, Youth and Sport of the Czech Republic and Ministry of Education, Science, Research and Sport of the Slovak Republic in 1999 (Bahna 2013). According to Bernát (2013), Slovak students accounted for $61 \%$ of students at the Faculty of Mechanical and Electro-technical Engineering at the Technical University of Brno during the interwar period 1918/1919-1939/1940 (for comparison, there were just $13 \%$ of the Czech students at the time). This can partly be explained by the lack of technical universities in Slovakia.

This emigration for education is such a serious problem that the Ministry of Education, Science, Research and Sport of the Slovak Republic developed a grant program "Návrat domov" (Home-coming) in Mai 2015. Over the period 2015-2018, three million euros will be paid for scholarships of $10000-50000$ $€$. The recipients of these scholarships should be young Slovaks willing to return to the Slovak Republic (MSVVS SR, 2015).

The Slovak brain drain can be also considered as Czech brain gain. According to the recent surveys, Slovak students who study at Czech Higher Education Institutes (HEIs) belong to Slovak elites (Scio 2015 or Bahna 2015). Almost 70\% of Slovak 
high school elite (Scio 2015 defines "elite" as 10\% of the best high school's pupils) have considered studying in the Czech Republic (Scio 2015). Students from highly educated families dominated those willing to move (Bahna 2015), which supports the intergenerational transmission theory (Fischer, Lipovska, 2013). Nearly one half of Slovak students are going to remain in the Czech Republic even after graduation (Němec et al., 2015). Recent research by Němec et al. even tried to calculate the financial costs and benefits of Slovak students in the Czech Republic (ibidem). The international brain drain might be also beneficial in terms of the threat of academic inbreeding (Fischer, Lipovská, 2015).

In 2014/2015, three unique surveys have been conducted on Slovak students at Czech HEIs:

- Brain drain 2014 - a survey conducted by the Institute for Sociology of the Slovak Academy of Sciences in 2014. The survey was carried out among 200 parents of Slovak students who studied abroad during period 1993-2012. The main aim of this survey was to discover who the Slovak students studying abroad are, how many of them remain abroad and the factors influencing their decision coming home (Bahna 2015).

- $\quad$ Scio survey - a survey conducted in 2014 among 14224 Slovak pupils from 173 schools. This survey discovered who the Slovak pupils that consider studying in the Czech Republic are (Scio 2015).

- Masaryk University, Faculty of Economics and Administration - the main aim of this research was to quantify the costs and benefits associated with Slovak students at Czech HEIs, especially at Masaryk University. This research also included a survey based on snowball sampling among 580 Slovak students who have recently studied in the Czech Republic (Němec 2015).

Each of these three surveys deals with the Slovak brain drain from a very different point of view and focus on completely different goals. Although these results are really valuable, they do not (and cannot) discover the complete profile of Slovak students at Czech HEIs. The aim of this paper is to fill this gap in our knowledge using unique data from two nationwide surveys in the Czech Republic: Eurostudent V and DOKTORANDI 2014. The rest of the paper is organised as follows. We shall introduce the data and statistical methods we used. We will then present the results of our analysis. First, a basic profile of Slovak students in the Czech Republic is created. Second, we shall focus on the financial situation of these students, which might be an important input for further analysis. In the next part, the intergenerational transmission is analysed. Finally, the threat of a further brain drain of Slovak students - from the Czech Republic elsewhere - is examined.

\section{Materials and Methods}

Our research is based on two unique datasets. The EUROSTUDENT V ${ }^{1}$ survey was conducted in 2013 among all Czech public and state HEIs and 29 private HEIs. In total 95,177 students of bachelor's and master's degrees were addressed with a response rate just below 7 \% (Fischer, Vltavská, 2013). The final original dataset includes 4,664 respondents, whose responses were weighted according to the Union Students Register information system. For the aim of our research, this

1 This survey was carried out in the Czech Republic, within the project IPN KREDO CZ.1.07/4.1.00/33.0005. dataset was further narrowed down to 4,577 respondents Czech and Slovak high school graduates. This narrowed dataset was divided into two groups:

- Czech students - 4,311 respondents, who attained secondary education in the Czech Republic.

- Slovak students - 266 respondents, who attained secondary education in the Slovak Republic.

Slovak and Czech students could also be distinguished in a different way: according to their mother tongue, country of birth or their parents' country of birth. However, these indicators were less suitable with regard to the objectives of our research, because most of the respondents were born during the Czechoslovak federation. Clustering respondents according to their country of education also better reflects the human capital investments problem. From a public budget point of view, it is indifferent if the country invested into the secondary education of the Czech, the Slovak or the Hungarian, the only thing which matters is that this human capital recipient participates in the "education emigration".

For further analysis, two dummy variables were developed. The first dummy variable acquired a value of 1 if both parents received higher education (gained bachelor's degree, master's degree or a $\mathrm{PhD}$ ) and a value of 0 if at least one of the parents gained lower level of education. The second dummy variable reflects the parental status in terms of blue-collar and whitecollar workers (see Table 1). This dummy variable acquired a value of 1 if both parents are white-collar workers.

\begin{tabular}{|c|l|c|l|}
\hline ISCO-08 & White-collar & ISCO-08 & \multicolumn{1}{|c|}{ Blue-collar } \\
\hline 1 & Managers & 6 & $\begin{array}{l}\text { Skilled agricultural, } \\
\text { forestry and fishery } \\
\text { workers }\end{array}$ \\
\hline 2 & Professionals & 7 & $\begin{array}{l}\text { Craft and related trades } \\
\text { workers }\end{array}$ \\
\hline 3 & $\begin{array}{l}\text { Technicians } \\
\text { and associate } \\
\text { professionals }\end{array}$ & 8 & $\begin{array}{l}\text { Plant and machine } \\
\text { operators, and } \\
\text { assemblers }\end{array}$ \\
\hline 4 & $\begin{array}{l}\text { Clerical support } \\
\text { workers }\end{array}$ & 9 & Elementary occupations \\
\hline 5 & $\begin{array}{l}\text { Service and } \\
\text { sales workers }\end{array}$ & & \\
\hline
\end{tabular}

Table 1: Blue-collar and white-collar workers

The concentration of HEIs in terms of student nationalities is measured with the Herfindahl-Hirschman index (HHI, see e.g.

Bauer et al., 2015), where $s_{i}$ is the ratio of Czech (respectively

Slovak) students attending $i$ th HEI. The Herfindahl-Hirschman Index (1) can range from 0 (large variance) to 1 (all students study at the same HEI):

$$
\boldsymbol{H H I}=\sum_{i=1}^{n} \boldsymbol{s}_{i}^{2}
$$

The second dataset is based on the survey DOKTORANDI $2014^{2}$, which was carried out in 22 public, 2 state, and 2 private HEIs among more than 24 thousand $\mathrm{PhD}$ students in spring 2014

2 This survey was carried out in the Czech Republic within the project IPN KREDO CZ.1.07/4.1.00/33.0005. 
(Fischer, Vltavská, 2014). The response rate was approximately $15 \%$ and the final data set consists of 3,283 respondents. This survey did not allow for making a direct distinction between Czech and Slovak students. To select Slovak students, we focused on the language of several open-ended questions (e.g. "Why did you decide to study PhD doctoral program?"). This method has considerable weaknesses: it does not allow us to distinguish Slovak students who write in fluent Czech, which could be a considerable majority of them. In addition to this, it guarantees that non Czech students would be labelled as a Slovak student. Under this procedure, we received a narrow down dataset of 70 Slovak students in the Czech doctoral programs.

The statistical software STATISTICA 12 was used to perform standard methods of descriptive statistics, an analysis of variance (Budíková et al., 2010).

\section{Results}

This section is divided into four chapters. First, we shall present a profile of Slovak students in the Czech Republic and compare them with Czech students. Then we will evaluate their financial situation in terms of their income, expenses and their working activity, again in comparison with Czech students. The third part is devoted to intergenerational transmission. The highest level of parental education, as well as parental occupation of Slovak and Czech students, is analysed. Last but not least, we shall focus on Slovak PhD students at Czech universities and their plans for the future.

\section{Who are the Slovak students in the Czech Republic?}

\section{A profile comparison with Czech students}

According to our dataset, among Slovaks at Czech HEIs, male students significantly prevail (see Fig. 1). While male students account for nearly half of Czech students (with female students holding a majority), among Slovak students they account for two thirds. Only 5\% of Slovak students study at Czech private HEIs (compared to $11.4 \%$ of all respondents).

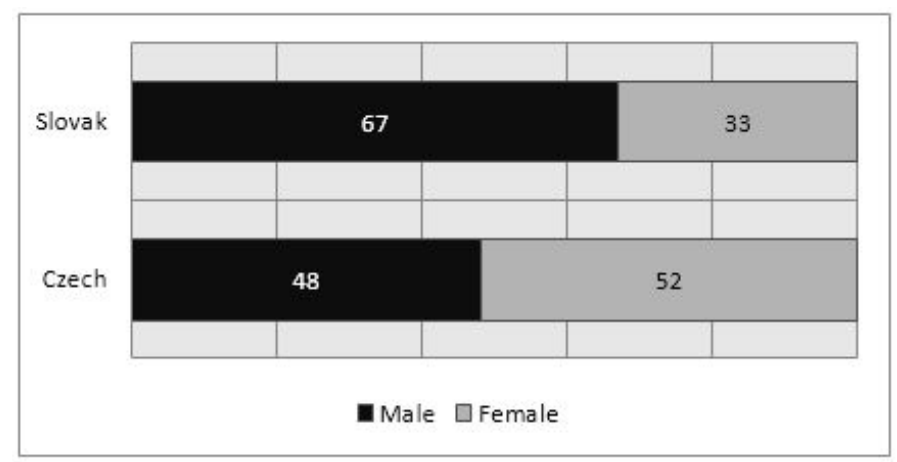

Figure 1: The proportion of male and female students among Slovaks and Czechs at Czech HEIs

There is also a significant difference between Slovak and Czech's fields of study. Slovak students relatively predominate in the field of Natural sciences, Healthcare sciences and Pharmacy, and Art. On the other hand, a majority of the Czech respondents major in Economics, Technical sciences and Education (see Figure 2).

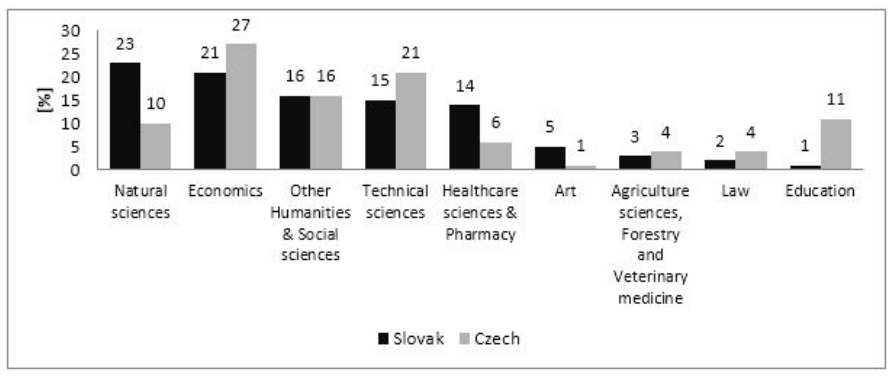

Figure 2: Field of study

Slovak students speak more foreign languages than Czech students (see Figure 3). Nearly 50\% Czech students have some language skills in at least four foreign languages, which is considerably less in comparison with nearly $3 / 4$ of Slovak students at Czech HEIs. This is certainly caused by knowledge of Czech - $100 \%$ of Slovak respondents claim that they can use (even at a low-level) Czech. On the other hand only $4 \%$ of Czech students mentioned knowledge of Slovak. Nearly $100 \%$ of Slovak students claim to speak English (compared to $98 \%$ of Czech students), 95\% self-evaluated their English knowledge as very good or good (compared to $79 \%$ of Czech students).

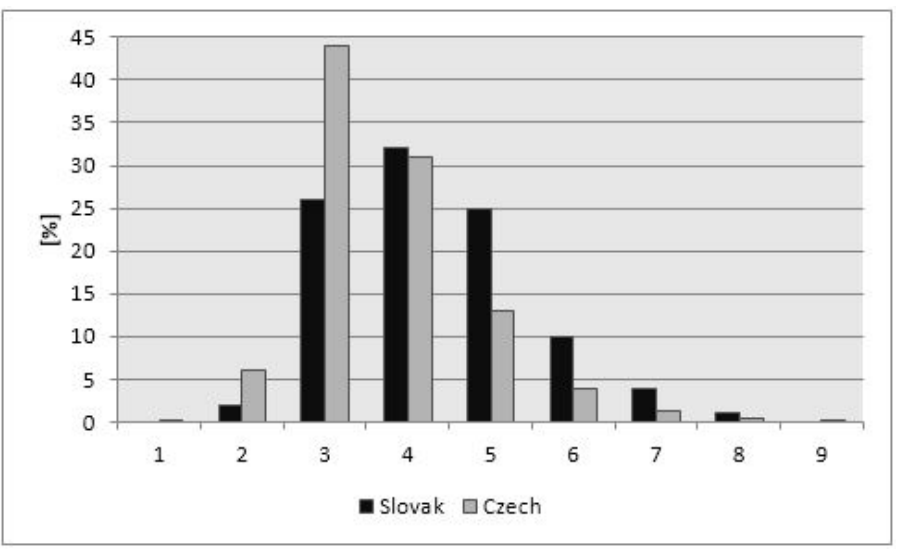

Figure 3: Number of languages students speak

There is also a smaller differentiation between the specific HEIs which Slovak students attend. While Slovak respondents study at 26 Czech HEIs, Czech respondents come from 56 Czech HEIs. Nearly two thirds of Slovak students study at only 4 HEIs (23\% at Charles University, 19\% at Masaryk University, 12\% at the University of Economics in Prague and 10\% at the Czech Technical University in Prague), while $65 \%$ of Czech students attend 8 HEIs (see Figure 4). The Slovak Herfindahl-Hirschman Index is therefore 0.12 compared to a Czech HerfindahlHirschman Index of 0.07 .

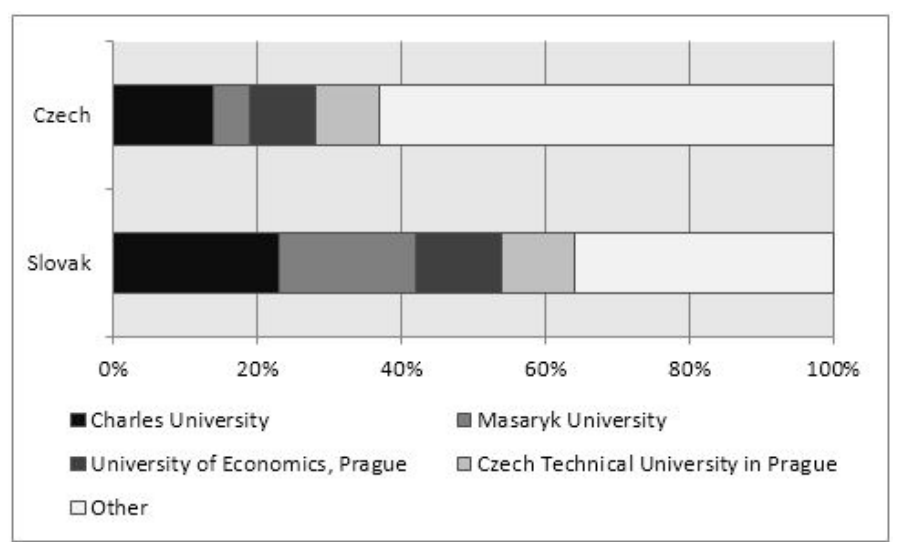

Figure 4: Slovak and Czech students at Czech HEIs

There is no significant difference in total satisfaction with a university's quality between Czech and Slovak students. 78\% of Slovaks are satisfied or very satisfied and $77 \%$ of Czech 
students. Nevertheless, significantly more Slovak students (37\%) in comparison to Czechs (30\%) are 'very satisfied'. The HEI at which they study was the first choice for $86 \%$ of Slovaks and only for $3 / 4$ of Czechs. Slovaks also feel to be integral part of their school slightly more often than Czechs $(83 \%$ in comparison with 78\%). For the Slovak students, the most important reason in decision to enter their study program was the career opportunities (79\%) and interest in the subject (78\%). On the other hand, the least important reason was the distance from their family (this factor is very important or important for just $1 / 4$ of Slovak students, in comparison with nearly $1 / 2$ of the Czech students). Most Czech and Slovak students would both enter their university again as mature students $(89 \%$ of Slovak and $84 \%$ of Czech students).

\section{Slovak students and a financial point of view}

The average monthly disposable income of the Slovak students was $14,335 \mathrm{CZK}$, which is more than 3,000 CZK higher than the income of the Czech students $(11,086 \mathrm{CZK})$. The difference between the median income is smaller, but also significant (8,500 CZK for Slovak and 7200 CZK for Czech students).

The average monthly expenses of the Slovak students are $9,035 \mathrm{CZK}$. The students pay $42 \%$ out of their own pockets; while $68 \%$ of their average monthly expenses are paid by parents, a partner or somebody else (see Figure 5). Most of their expenditures are the Total accommodation costs $(3,633$ CZK, 40\% of total expenditure) and Food (2,607 CZK, 29\% of total expenditure). The students themselves pay out of their own pocket predominantly for their Social and leisure activities $(62 \%)$, on the other hand $2 / 3$ of their total accommodation costs are paid for them by somebody else.

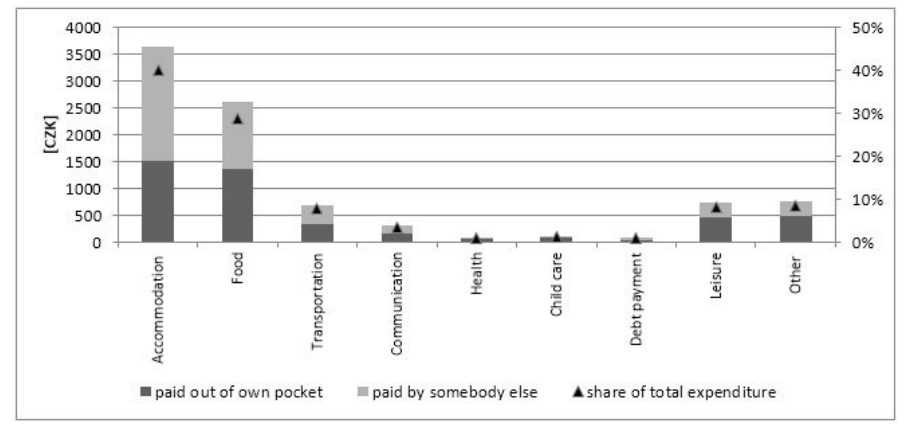

Figure 5: Average monthly expenses of a Slovak student [in Czech crowns CZK]

Slovak students live significantly more often in student accommodation during the semester. $53 \%$ of Slovaks live in halls of residence compared to only $31 \%$ of Czech students. Slovak students use public transport slightly more often $(77 \%$ of Slovak and $70 \%$ of Czech students). Slovak students also claim that they do not have serious financial difficulties more often than the Czech students, (61\% Slovaks compared to $56 \%$ Czechs).

Two thirds of the Czech students work during the whole term or at least from time to time during the term. This is true for only about half of the Slovak students at Czech HEIs. On the other hand, there is no significant difference in total hours spent on paid jobs or paid internships in a typical week in term time between Slovak students (23 hours) and Czech students (22 hours). Half of the working Slovak students claim that their job is not closely related to the content of their study program. On the other hand, only one third see a close or even very close relationship between their job and study program. This is not very different from the situation of the Czech students (see Figure 6).

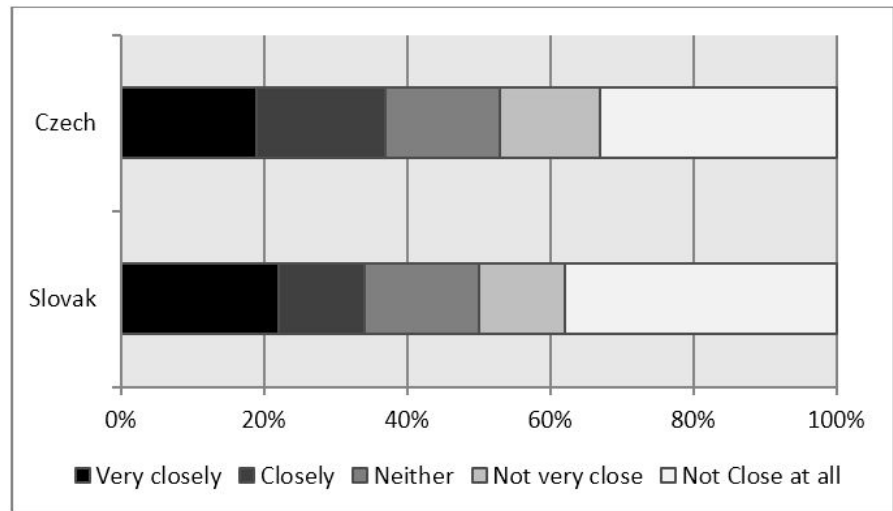

Figure 6: How closely related is the job of the Czech and Slovak students to their study program at Czech HEIs?

\section{Intergenerational transmission}

Slovak students come significantly more often from families with higher (tertiary) education. Nearly $70 \%$ of Slovak students at the Czech HEIs have at least one parent with higher education (compared to $46 \%$ of Czech students). The highest education level of the mother is even more important. The mothers of Slovak students at Czech HEIs reached tertiary education nearly twice more often than mothers of Czech students (see Figure 7). More than half of Slovaks at Czech HEIs have parents who both attained at least a bachelor degree, in comparison with nearly one third of Czech students.

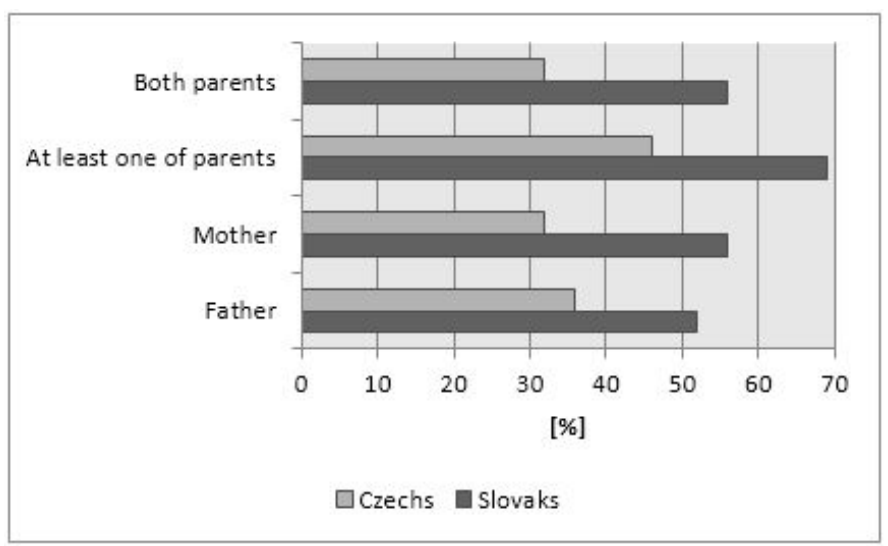

Figure 7: Parental higher education

There is no significant difference in the structure of parental occupation between the Slovak and Czech students. Nevertheless, as figure 8 clearly depicts, Slovaks who study at Czech HEIs come slightly more often from completely white-collar families ( $72 \%$ in comparison with $65 \%$ in the case of Czech students).

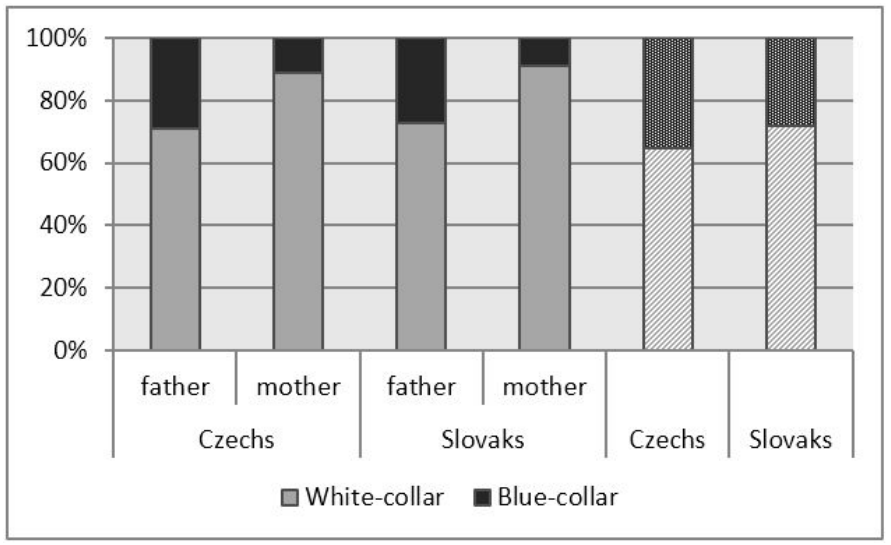

Figure 8: Parental occupation 
As figure 9 clearly depicts, Slovak students at Czech HEIs are significantly more often graduates from grammar schools $(80 \%$ in compared to $60 \%$ of Czech students).

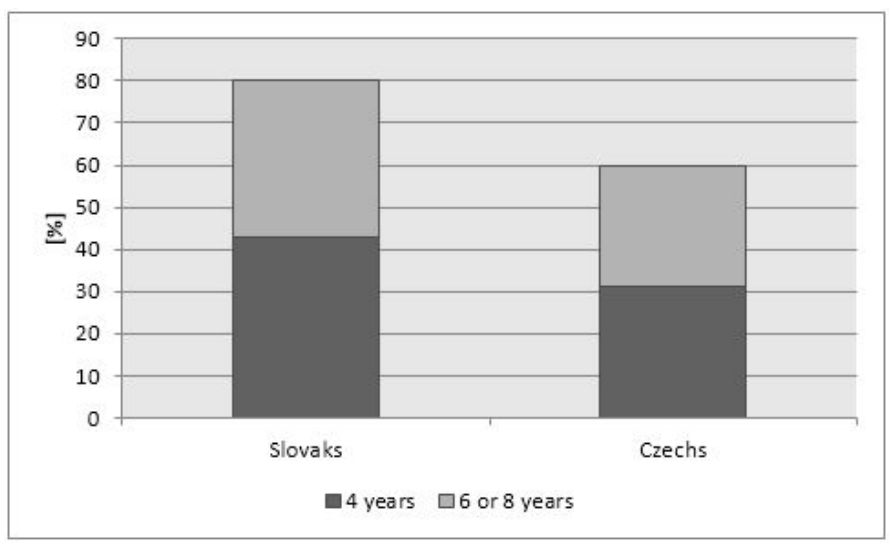

Figure 9: Proportion of grammar school graduates

\section{Brain gain and brain drain}

Slovak students participate slightly more often in the international mobility. While only $31 \%$ of Czech students studied or are planning to study abroad, the same is true for $44 \%$ of Slovak students.

Among the Slovak students in doctoral programs at Czech HEIs, only $34 \%$ want to stay in the Czech Republic, while $21 \%$ of them want to go abroad (outside the Czech Republic or Slovak Republic) and 6\% are planning to go back to the Slovak Republic $^{3}$. There is also a certain brain drain from academia - only $21 \%$ of $\mathrm{PhD}$ students are planning to stay in Czech or foreign academia.

\section{Discussion}

Most of the Slovak respondents from the EUROSTUDENT $\mathrm{V}$ survey major in Natural sciences, Economics and Other Humanities and Social sciences. This finding is inconsistent with the original plans of Slovak pupils according to the Scio survey (2015). Most of them were planning to study Economics, Healthcare services and Pharmacy and IT at Czech HEIs. In fact, $21 \%$ of Slovak students do study Economics at Czech HEIs, however, Healthcare services are studied just by $14 \%$ and Technical sciences by $15 \%$.

Our findings on the average monthly expenses of Slovak students confirm the findings of Němec et al. (2015). According to Němec, the total expenses of Slovak students are 9203 CZK (which is nearly the same result as our $9035 \mathrm{CZK}$ ). The total accommodation costs account for $35 \%$ of total expenses according to Němec (in comparison with $40 \%$ according to our results).

Slovak students at Czech HEIs use social benefits more often than the Czech students. About half of them live in the halls of residence, which is entirely consistent with the findings published by Němec ( $53 \%$ and $48 \%$ respectively). Also, our results on the working activity of Slovak students are in accordance with other surveys. According to Němec, $51 \%$ of Slovak students work during the term, which does not significantly differ from our result of $54 \%$.

Bahna (2015) points out that while $15 \%$ of Slovak students

3 The rest of the Slovak PhD students at the Czech HEIs do not revealed having clear future plans. at Slovak HEIs are from highly educated families, with both parents being university graduates, the same is true for $46 \%$ of Slovak students studying abroad. This is consistent with our findings, however, this difference is even more marked: $56 \%$ of Slovak students at Czech HEIs claimed their both parents have at least a bachelor's degree. The most likely explanation for this lies in the intergenerational transmission mechanism (e.g. Fischer, Lipovska 2013 or Antoni 2011). According to this concept, children from families with a higher stock of human capital tend to accumulate more human capital. In case of Slovak students, it is likely that higher-educated parents are more aware of the lower quality of Slovak HEIs, ${ }^{4}$ so they want their children to study abroad. Moreover, most of these students came from middle or higher class families. According to Němec (2015), more than $80 \%$ of Slovak students at Czech HEIs claim to come from at least middle class families, which is entirely consistent with our results of nearly $3 / 4$ of students from fully white-collar families.

Our findings also confirmed the higher share of grammar school graduates among Slovaks studying in the Czech Republic. Our result of $80 \%$ is generally consistent with $86 \%$ according to Bahna (2015). Bahna also mentions that there are only $36 \%$ grammar school graduates among Slovaks. Even more alarming, in terms of Slovakia's human capital outlook, is the enormously high rate of grammar school pupils considering studying at Czech HEIs (40\%-50\% of pupils, according to the Scio survey 2015).

According to the Scio survey, 10\% of Slovak pupils are going to remain in the Czech Republic if they study at a Czech HEI (Scio 2015). Němec points out that this rate grows to $40 \%$ after Slovak students spend a certain amount of time in the Czech Republic. While $18 \%$ of 'fresh' Slovak students at Czech HEIs think about home-coming, this rate falls to merely $11 \%$ after time spent in the Czech Republic (Němec 2015). We found that only $6 \%$ of Slovak PhD students want to return to Slovakia. This might be explained by the very long time $\mathrm{PhD}$ students spent in the Czech Republic - they create new social networks, learn the language, perhaps raise a new family and lose their original ties to Slovakia. On the other hand, Slovak PhD students are also more willing to leave even the Czech Republic and go further abroad. This finding is consistent with the presumed higher ambitions of these Slovak students (see Bahna 2015).

\section{Conclusion}

The Slovak brain drain to Czech HEIs is a widely discussed phenomenon. The popularity of this problem has grown over time as the number of young Slovaks leaving their country reaches new records. The Czech Republic is a natural receiving country because of the long and successful historical ties between both Slavic nations, the similarity of the Czech and Slovak language, the short distance between Slovak and Czech (especially Moravian) towns, and legislative arrangements.

Slovak students who leave their families and friends to enrol in Czech HEIs profit from a (probably) higher quality of education and social support. They live in halls of residence more often than Czech students, use international exchanges more frequently and make the most of the public/social services. For example, we have shown that Slovak students use public transportation slightly more often than Czech students, while from 2012, all

$4 \quad$ For more on the quality of Slovak HEI's, see e.g. reports of the Slovak Academic ranking and rating agency (ARRA 2014). 
students from the EU countries have had the same price benefits as the Czech students (Povolný 2012).

According to Bahna (2015), more than $40 \%$ of Slovak graduates from foreign HEIs return to the Slovak Republic. This $40 \%$ are certainly beneficial for the Slovak economy. This part of Slovak human capital was financed from foreign budgets, but the real revenues will be harvested in the Slovak Republic. The serious problems for the Slovak economy are those who do not return. This almost $50 \%-60 \%$ of "lost brains" means not only a lost initial Slovak investment, but also unrealized intellectual potential. In the light of these results, the grant program "Homecoming" (initiated by the Ministry of Education, Science, Research and Sport of the Slovak Republic) seems to be a very logical effort. However, the four-year grant program managed bring back only one third of Slovak students who studied at Czech HEIs in 2013.

Our findings on the Slovak brain-drain to the Czech Republic confirm that these students are members of the Slovak elite. They come from highly educated middle and higher class families, they belong to the best secondary school graduates and they study promising sciences. According to Nermec et al. (2015), the Czech costs on their education are more than repaid by their benefit to the Czech economy. Moreover, the higher rates of Slovak students at Czech HEIs help the respective school to do better in the intra-national as well as the international ranking and rating systems. Indeed, most of the rankings observe the number of foreign students at the HEI, with Slovak students considered as 'foreign'.

The Slovak brain-drain seems to be a Czech brain-gain because of the high quality, as well as 'internationality', of the incoming students. The logical effort of the Slovak Ministry of Education to bring back these "educational emigrants" means a certain threat for the Czech stock of the human capital. It is a significant challenge of both Czech and Slovak HEIs and governments to find a satisfactory level of international cooperation. We suggest intergovernmental discussion between the Czech and Slovak Ministry of Education to unify the educational strategies and clarify the conditions of such federative consequences.

\section{Acknowledgements}

This work was written thanks to the Institutional Support to LongTerm Conceptual Development of the Research Organisation of the Faculty of Informatics and Statistics of the University of Economics, Prague and was supported by the project No. MUNI/A/1223/1204, funded by Masaryk University.

\section{References}

Antoni, M. (2011), 'Lifelong learning inequality? The relevance of family background for on-the-job training', IAB-Discussion Paper, 9/2011, Nuremberg.

Bahna, M. (2013). 'Dve dekády medzinárodnej migrácie zo Slovenska: od otvorenia hraníc po otvorenie pracovného trhu' [Two decades of international migration from Slovakia: from the border to the labor market opening] In V. Krivý, ed. Ako sa mení slovenská spoločnost'. Sociologický ústav SAV, pp. 355383.

Bahna, M. (2015), 'Slovenskí absolventi vysokoškolského štúdia v zahraničí: Únik mozgov, alebo otvárajúce sa mobilitné kanály na Slovensku?' [Slovak graduates: Brain drain or opening mobility channels in Slovakia], SAV-Working Paper, 1/2015, Bratislava.
Bernát, L. (2013), 'Slovak students at the Faculty of Mechanical and Electrotechnical Engineering of the Czech Technical University in Brno during the intercensal period'. Slovak Statistics and Demography, vol. 23, No. 2, pp. 49-68.

Budíková, M. et al. (2010) Průvodce základními statistickými metodami [Guide to basic statistical methods], Prague: Grada Publishing, a.s.

Bauer, L. et al. (2015) Matematika v ekonomii a ekonomice [Mathematical in economics and economy], Prague: Grada Publishing, a.s.

Fischer, J. and Lipovská, H. (2013) 'Building human capital: The impact of parents' initial educational level and lifelong learning on their children'. Journal of Efficiency and Responsibility in Education and Science, vol. 6, No. 4, pp. 218-231. doi: 10.7160/ eriesj.2013.060402

Fischer, J. and Lipovská, H. (2015) 'Academic inbreeding in the Czech Republic' Proceedings of the $12^{\text {th }}$ International Conference on Efficiency and Responsibility in Education (ERIE 2015), Prague, pp. 112-119.

Fischer, J. and Lipovská, H. (2015) 'Doctoral brain drain from Czech academia' Proceedings of the $12^{\text {th }}$ International Conference on Efficiency and Responsibility in Education (ERIE 2015), Prague, pp. 120-126.

Fischer, J. and Vltavská, K. (2013) EUROSTUDENT V: 'Základní výsledky šetření postojů životních podmínek studentů vysokých škol v České republice. ' [EUROSTUDENT V: basic results of the survey among students at the Czech HEIs] Prague. Available: http://kredo.reformy-msmt.cz/podminky-studentuvs-soubor

Fischer, J. and Vltavská, K. (2014), DOKTORANDI 2014: 'Základní výsledky šetření postojů studentů doktorských studijních programů vysokých škol v České republice.' [DOKTORANDI 2014: basic results of the survey among PhD students at the Czech HEIs] Prague.

OECD (2014), 'Indicator C4: Who studies abroad and where?', in Education at a Glance 2014: OECD Indicators, OECD Publishing, Paris. http://dx.doi.org/10.1787/888933118656

Mazouch, P. and Fischer, J. (2011) Lidský kapitál - měření, souvislosti, prognózy [Human capital - measuring, context, prognosis], Prague: C. H. Beck

MF CR (2015) Státní rozpočet 2015 v kostce [State budget 2015 in a nutshell], Prague: Ministerstvo financí

MSVVS SR (2015), 'Grantový program - Návrat domov' [Grant program - Home-coming]. Available: http://www.minedu.sk/ grantovy-program-\%E2\%80\%93-navrat-domov/

Němec, D. et al. (2015) 'Náklady a výnosy studia slovenských studentů Masarykovy univerzity a vysokých škol v České republice' [Costs and benefits of the Slovak students studying at Masaryk University and Czech HEIs], Working paper. Brno: Faculty of Economics and Administration, Masaryk University. Povolný, D. (2012) 'Studentka vybojovala žákovské jízdné i pro cizince' [Student won the student fares even for foreigners]. Online-Muni, Brno: Masarykova unvierzita

Available:http://www.online.muni.cz/student/2878-slovenskastudentka-vybojovala-zakovske-jizdne-i-pro-lidi-ze-zahranici\#. VdtY5pc71N6

Rapoport, H. (2002) 'Who is afraid of the brain drain? Human capital flight and growth in developing countries', SIEPR Policy Brief. Stanford.

Scio (2015) 'Slovenští maturanti se opět chystají do ČR' [Slovak graduates are once again going to the Czech Republic], Working Paper. Prague: Scio. 